\title{
Systemic Inflammation and Its Response to Treatment in Patients With Asthma
}

\author{
Ankur Girdhar MD, Vivek Kumar MD MPH, Amita Singh MD, \\ Balakrishnan Menon MD, and VK Vijayan MD
}

\begin{abstract}
BACKGROUND: Asthma is an obstructive airway disease characterized by airway inflammation. OBJECTIVE: To measure systemic inflammation in asthma patients, and to assess the effect of treatment on systemic inflammation. METHODS: In 30 newly diagnosed non-randomized adult asthma patients we measured systemic inflammation markers (serum high-sensitivity C-reactive protein, total leukocyte count, and erythrocyte sedimentation rate) before and after a 6-week standard treatment with inhaled steroids and inhaled $\boldsymbol{\beta}_{2}$ agonist. The comparison group comprised 20 healthy control subjects. All the subjects were non-smokers. RESULTS: The measured systemic inflammation markers were higher in the asthma patients: high-sensitivity C-reactive protein $4.8 \pm 6.0 \mathrm{mg} / \mathrm{dL}$ vs $1.5 \pm 1.4 \mathrm{mg} / \mathrm{dL}$, $P<.001$; total leukocyte count $8,936 \pm 2,592$ cells $/ \mu \mathrm{L}$ versus $7,741 \pm 1,924$ cells $/ \mu \mathrm{L}, P<.001$; erythrocyte sedimentation rate $24.8 \pm 12.3 \mathrm{~mm} / \mathrm{h}$ versus $15.3 \pm 6.5 \mathrm{~mm} / \mathrm{h}, P<.001$. In the asthma patients, high-sensitivity $C$-reactive protein negatively correlated with percent-of-predicted $F E V_{1}$ $(\mathrm{r}=-0.64, P=.001)$, percent-of-predicted forced vital capacity $(\mathrm{FVC})(\mathrm{r}=-0.39, P=.03), \mathrm{FEV}_{1} /$ FVC\% $(r=-0.71, P<.001)$, and percent-of-predicted forced expiratory flow during the middle half of the FVC maneuver $\left(\mathrm{FEF}_{25-75}\right)(\mathrm{r}=-\mathbf{0 . 5 1}, P=.004)$. Total leukocyte count negatively correlated with percent-of-predicted $\mathrm{FEV}_{1}(\mathrm{r}=-\mathbf{0 . 6 4}, P=.001)$, percent-of-predicted $\mathrm{FEV}_{1} / \mathrm{FVC}(\mathrm{r}=-0.74, P<.001)$, and percent-of-predicted $\mathrm{FEF}_{25-75}(\mathrm{r}=-\mathbf{0 . 5 8}, P=.001)$. Body mass index positively correlated with high-sensitivity $\mathrm{C}$-reactive protein $(\mathrm{r}=0.65, P<.001)$. Multiple linear regression showed significant correlation of high-sensitivity $C$-reactive protein $\left(r^{2}=0.75\right)$ with age $(\beta=0.31, P=.008)$, body mass index $(\beta=0.99, P=.001)$, family size $(\beta=0.33, P=.008)$, and weight $(\beta=-0.45, P=.01)$. The systemic inflammation markers decreased significantly $(P<.001$ for all comparisons) after 6 weeks of treatment: high-sensitivity C-reactive protein decreased from $4.8 \pm 6.0 \mathrm{mg} / \mathrm{dL}$ to $2.4 \pm 5.4 \mathrm{mg} / \mathrm{dL}$, total leukocyte count decreased from $8,936 \pm 2,592$ cells $/ \mu \mathrm{L}$ to $6,960 \pm 1,785$ cells $/ \mu \mathrm{L}$, and erythrocyte sedimentation rate decreased from $24.8 \pm 12.3 \mathrm{~mm} / \mathrm{h}$ to $15.8 \pm 10.1 \mathrm{~mm} / \mathrm{h}$. CONCLUSIONS: Inhaled steroids plus inhaled $\boldsymbol{\beta}_{2}$ agonist significantly reduced systemic inflammation in asthma patients. Key words: asthma; systemic inflammation; high-sensitivity C-reactive protein; acute phase reactants; inhaled corticosteroids. [Respir Care 2011;56(6):800-805. (c) 2011 Daedalus Enterprises]
\end{abstract}

Introduction

Drs Girdhar and Singh are affiliated with the Department of Internal Medicine; and Dr Kumar is affiliated with the Department of Emergency Medicine, University of Florida College of Medicine, Jacksonville, Florida. Drs Menon and Vijayan are affiliated with the Vallabhbhai Patel Chest Institute, Clinical Research Centre, Delhi University, New Delhi, India.

Dr Girdhar presented a version of this paper at the American College of Chest Physicians' 73rd Annual International Scientific Assembly, held October 20-25, 2007, in Chicago, Illinois.

The authors have disclosed no conflicts of interest.
Asthma is characterized by airway hyper-responsiveness and inflammation that is mediated by various cellular elements and cytokines. The inflammation is both local to

Correspondence: Ankur Girdhar MD, Department of Internal Medicine, University of Florida College of Medicine, 653-1 West 8th Street, Jacksonville FL 32209. E-mail: ankurgirdhar@yahoo.com.

DOI: $10.4187 /$ respcare.00601 
the lungs and systemic, ${ }^{1-3}$ and may be a risk factor for cardiovascular comorbidities. ${ }^{4}$

Measurements of serum C-reactive protein have suggested low-grade systemic inflammation in several disorders such as cardiovascular diseases, diabetes mellitus, peripheral vascular diseases, and infections. ${ }^{5-8}$ Furthermore, a recent study found an association between elevated serum C-reactive protein and a higher frequency of airway hyper-responsiveness and low $\mathrm{FEV}_{1}$ among subjects without heart disease, ${ }^{9}$ which suggests that systemic inflammation may be associated with respiratory impairment. Another recent epidemiological study found that elevated C-reactive protein correlated significantly with respiratory symptoms and with non-allergic asthma. ${ }^{2}$ We also know that inflammation is associated with elevated acute-phase reactants such as total leukocyte count and erythrocyte sedimentation rate. ${ }^{1}$ We studied systemic inflammation in asthma patients, and the effect of a standard asthma treatment regimen on systemic inflammation.

\section{Methods}

The study was conducted at the out-patient clinic of Vallabhbhai Patel Chest Institute, Delhi University, New Delhi, India, between April 2006 and March 2007. The study was approved by Delhi University's institutional ethics committee, and all subjects gave informed consent.

\section{Population}

In our out-patient clinic we recruited 30 newly diagnosed adult asthma patients, diagnosed per the Global Initiative for Asthma guidelines. ${ }^{10}$ Twenty healthy, asymptomatic control subjects were recruited from the families of asthma patients by confirming their healthy status with clinical examination, chest radiograph, and pulmonary function tests. All the newly diagnosed asthma patients were either treatment naïve or on rescue inhaler only. We excluded patients who were on medications that can affect inflammation (eg, leukotriene inhibitors, theophylline, or oral steroids), and patients with heart disease, diabetes mellitus, cancer, obesity (body mass index [BMI] $>30 \mathrm{~kg} /$ $\mathrm{m}^{2}$ ), and systemic inflammatory disorders (eg, collagen vascular diseases). None of the asthma patients were smokers or had a respiratory tract infection or an asthma exacerbation during the month before enrollment.

\section{Systemic-Inflammation Markers}

We measured C-reactive protein, total leukocyte count, and erythrocyte sedimentation rate because of easy availability and ease of use in the local laboratories. Peripheral venous blood samples were centrifuged for $10 \mathrm{~min}$ at 1,300 relative-centrifugal-force at $4^{\circ} \mathrm{C}$. The sera were stored at $-60^{\circ} \mathrm{C}$ till analysis. The blood sample were always taken at the same time in the morning, after an overnight fast. Serum C-reactive protein was measured with a highsensitivity automated enzyme-linked immunosorbent assay reader (microplate imunoenzymometric assay, Monobind, Lake Forest, California), with a sensitivity of $0.2 \mathrm{mg} / \mathrm{L}$. Erythrocyte sedimentation rate was measured with the Wintrobe method, and total leukocyte count was via hemocytometer with diluted blood. The total-leukocyte-count differentials were measured via microscopy of peripheral smears.

\section{Pulmonary Function}

Pre-bronchodilator spirometry (Benchmark/CPL/Spiro 232, PK Morgan, New Delhi, India) included $\mathrm{FEV}_{1}$, forced vital capacity (FVC), $\mathrm{FEV}_{1} / \mathrm{FVC}$, and forced expiratory flow during the middle half of the FVC maneuver $\left(\mathrm{FEF}_{25-75}\right)$. The patients were asked to stop using bronchodilators for 6 hours and oral theophylline for at least 24 hours prior to post-bronchodilator testing. Post-bronchodilator testing was after $200 \mu \mathrm{g}$ of inhaled albuterol. We used the predicted values from Knudson et al. ${ }^{11}$ Systemic-inflammation markers and pulmonary function were re-measured after 6 weeks, during which the patients were on our standard asthma treatment.

\section{Standard Asthma Treatment}

We included only asthma patients who were not regularly taking inhaled corticosteroids prior to enrollment in the study. After enrolling, the patients were started on 6 weeks of asthma treatment, per the current Global Initiative for Asthma guidelines ${ }^{10}$ : inhaled long-acting $\beta_{2}$ agonist and corticosteroid combination (salmeterol 50$100 \mu \mathrm{g}$ daily and fluticasone $500-1,000 \mu \mathrm{g}$ daily) and as-needed, rescue dose of inhaled short-acting albuterol. During the treatment period we followed the patients at 2-week intervals, where they were assessed for adherence to therapy, adverse effects, and asthma exacerbations. We excluded patients who had an asthma exacerbation during the treatment period.

\section{Statistical Analysis}

Data were analyzed with statistics software (SPSS 18.0, SPSS, Chicago, Illinois), and we report frequencies, percents, and means and standard deviations. Analysis included performing the independent $t$ test, chi-square test, Mann-Whitney U test, and looking at the Pearson correlation coefficients. We used multiple linear regression analysis to assess the variance explained by groups of independent variables. Nonparametric tests were done because 
Table 1. Subjects

\begin{tabular}{|c|c|c|c|}
\hline & $\begin{array}{c}\text { Asthma } \\
\text { Group }\end{array}$ & $\begin{array}{c}\text { Control } \\
\text { Group }\end{array}$ & $P$ \\
\hline Subjects (no.) & 30 & 20 & NA \\
\hline Age $(y)$ & $35 \pm 12$ & $36.15 \pm 16.39$ & $.73 *$ \\
\hline Male/female (no.) & $13 / 17$ & $11 / 9$ & $.41 \dagger$ \\
\hline Weight $(\mathrm{kg})$ & $60.2 \pm 14.1$ & $61.1 \pm 16.5$ & $.85^{*}$ \\
\hline Height $(\mathrm{cm})$ & $159 \pm 10$ & $160 \pm 10$ & $.79 *$ \\
\hline Body mass index $\left(\mathrm{kg} / \mathrm{m}^{2}\right)$ & $23.7 \pm 4.2$ & $23.3 \pm 4.5$ & $.72 *$ \\
\hline Waist/hip ratio & $0.97 \pm 0.08$ & $0.95 \pm 0.01$ & $.31 *$ \\
\hline Skin-fold thickness (cm) & $1.7 \pm 0.3$ & $1.6 \pm 0.5$ & $.21 *$ \\
\hline Chest circumference $(\mathrm{cm})$ & $85 \pm 11$ & $81 \pm 9$ & $.24 *$ \\
\hline Family size (no.) & $5 \pm 2$ & $5 \pm 2$ & $.99 *$ \\
\hline Education Level, no. (\%) & & & $.20 \dagger$ \\
\hline Illiterate & $3(10)$ & $0(0)$ & \\
\hline Up to high school & $15(50)$ & $14(70)$ & \\
\hline College & $12(40)$ & $6(30)$ & \\
\hline Occupation, no. (\%) & & & $.08 \dagger$ \\
\hline Unemployed or housewife & $20(67)$ & $7(35)$ & \\
\hline Skilled & $7(23)$ & $10(50)$ & \\
\hline Unskilled & $3(10)$ & $3(15)$ & \\
\hline $\begin{array}{l} \pm \text { values are mean } \pm \mathrm{SD} \text {. } \\
* P \text { via independent } t \text { test. } \\
\dagger P \text { via chi-square test. } \\
\mathrm{NA}=\text { not applicable }\end{array}$ & & & \\
\hline
\end{tabular}

the data did not meet the assumptions for parametric tests. $P<.05$ was considered significant.

\section{Results}

\section{Subjects}

Table 1 describes the subjects. Sex, BMI, age, education, and occupation did not significantly differ between the asthma and the control groups.

\section{Pulmonary Function}

Table 2 shows the pulmonary function test results. Before starting the treatment, pre-bronchodilator $\mathrm{FEV}_{1}, \mathrm{FVC}$ $\%$ predicted, and $\mathrm{FEF}_{25-75}$ were significantly lower in the asthma patients than in the control group. After the 6-week treatment period, the $\mathrm{FEV}_{1}, \mathrm{FVC}$, and $\mathrm{FEF}_{25-75}$ difference between the asthma patients and the control subjects was not significant. In the asthma patients, after the 6-week treatment period there was significant improvement in prebronchodilator percent-of-predicted $\mathrm{FEV}_{1}$ and $\mathrm{FEF}_{25-75}$, and a not statistically significant increase in FVC.

\section{Systemic-Inflammation Markers}

Total leukocyte count, C-reactive protein, and erythrocyte sedimentation rate were significantly lower in the asthma patients after treatment (Table 3). The Mann-Whitney $U$ test indicated a statistically significant difference between the asthma patients and the control subjects. Assuming the null hypothesis of equal distribution of inflammation markers, due to a $P$ value of $>.05$ we concluded that the distribution of $C$-reactive protein $(P=.97)$, erythrocyte sedimentation rate $(P=.72)$, and total leukocyte count $(P=.10)$ was not significantly different between the post-treatment asthma group and the control group. The inflammation markers had significantly decreased in the post-treatment asthma group.

\section{Relationship Between Systemic-Inflammation Markers and Other Measurements}

In the asthma group, the pre-treatment C-reactive protein and total leukocyte count negatively correlated with percent-of-predicted $\mathrm{FEV}_{1}, \mathrm{FVC}$, and $\mathrm{FEF}_{25-75}$ (Table 4). Mean erythrocyte sedimentation rate did not correlate with the various other measurements in the asthma patients. BMI significantly correlated with C-reactive protein and total leukocyte count. When taking into account variables that showed a positive correlation in the bivariate analysis, multiple linear regression showed significant correlation of C-reactive protein $\left(\mathrm{r}^{2}=0.75\right)$ and age $(\beta=0.31$, $P=.008)$, body mass index $(\beta=0.99, P=.001)$, family size $(\beta=0.33, P=.008)$, and weight $(\beta=-0.45, P=.01)$, whereas erythrocyte sedimentation rate did not significantly correlate with those variables or pulmonary function variables such as percent-of-predicted $\mathrm{FEV}_{1}$ and FVC. Similarly, total leukocyte count significantly correlated only with weight $\left(\beta=-0.51, P=.03, \mathrm{r}^{2}=0.57\right)$ (Table 5).

\section{Discussion}

This study confirms the earlier findings of background systemic inflammation in patients with asthma. ${ }^{1-3}$ Systemic inflammation decreased significantly after 6 weeks of asthma treatment, although various treatment aspects were not examined. The importance of systemic inflammation in asthma and its effect on comorbidities merit further research.

To minimize confounders, we selected asthma and control groups that did not significantly differ in age, sex, obesity, education, or occupation. These factors have not been taken into account in previous studies of systemic inflammation in asthma. ${ }^{1-3}$

We also correlated the systemic-inflammation markers with various clinical measurements, and found significant negative correlation of the systemic-inflammation markers and $\mathrm{FEV}_{1}, \mathrm{FVC}, \mathrm{FEV}_{1} / \mathrm{FVC}$, and $\mathrm{FEF}_{25-75}$. Takemura et $\mathrm{al}^{3}$ found similar correlations between $\mathrm{C}$-reactive protein and pulmonary function. This implies that impaired respiratory function is associated with higher background systemic 


\section{Systemic Inflammation and Its Response to Treatment in Patients With Asthma}

Table 2. Pulmonary Function Test Results Before and After Treatment

\begin{tabular}{|c|c|c|c|c|c|c|}
\hline & \multicolumn{2}{|c|}{ Asthma Group $(\mathrm{n}=30)$} & \multirow{2}{*}{$\begin{array}{l}\text { Control } \\
\text { Group } \\
(\mathrm{n}=20)\end{array}$} & \multirow{2}{*}{$\begin{array}{c}P \text { Before vs } \\
\text { Control* }\end{array}$} & \multirow{2}{*}{$\begin{array}{c}P \text { After vs } \\
\text { Control } \dagger\end{array}$} & \multirow{2}{*}{$\begin{array}{c}P \text { Before vs } \\
\text { After } ¥\end{array}$} \\
\hline & Before Treatment & After Treatment & & & & \\
\hline \multicolumn{7}{|l|}{$\mathrm{FEV}_{1}(\mathrm{~L})$} \\
\hline Predicted & $3.0 \pm 0.7$ & $3.0 \pm 0.6$ & $3.1 \pm 0.8$ & .83 & .82 & .97 \\
\hline Before bronchodilator & $1.8 \pm 0.7$ & $2.3 \pm 0.8$ & $2.7 \pm 1.0$ & .002 & .22 & .001 \\
\hline After bronchodilator & $2.0 \pm 0.8$ & $2.5 \pm 0.7$ & $2.8 \pm 1.0$ & .003 & .16 & .005 \\
\hline$\%$ predicted before treatment & $59 \pm 21$ & $77 \pm 18$ & $84 \pm 11$ & $<.001$ & .08 & .001 \\
\hline$\%$ predicted after treatment & $66 \pm 19$ & $78 \pm 21$ & $85 \pm 22$ & .002 & .29 & .007 \\
\hline \multicolumn{7}{|l|}{$\mathrm{FVC}(\mathrm{L})$} \\
\hline Predicted & $3.6 \pm 0.9$ & $3.5 \pm 0.8$ & $3.6 \pm 0.9$ & .98 & .75 & 62 \\
\hline Before bronchodilator & $3.0 \pm 0.9$ & $3.3 \pm 0.9$ & $3.3 \pm 1.1$ & .28 & .87 & .08 \\
\hline After bronchodilator & $3.2 \pm 1.0$ & $3.5 \pm 1.0$ & $3.5 \pm 1.1$ & .41 & .89 & .002 \\
\hline$\%$ predicted before treatment & $82 \pm 16$ & $91 \pm 13$ & $92 \pm 12$ & .03 & .96 & .08 \\
\hline$\%$ predicted after treatment & $86 \pm 21$ & $95 \pm 23$ & $96 \pm 13$ & .06 & .89 & .17 \\
\hline \multicolumn{7}{|l|}{$\mathrm{FEV}_{1} / \mathrm{FVC}(\%)$} \\
\hline Before bronchodilator & $59 \pm 15$ & $77 \pm 17$ & $85 \pm 11$ & $<.001$ & .04 & .001 \\
\hline After bronchodilator & $63 \pm 15$ & $73 \pm 12$ & $86 \pm 11$ & $<.001$ & $<.001$ & .001 \\
\hline \multicolumn{7}{|l|}{$\mathrm{FEF}_{25-75}(\mathrm{~L} / \mathrm{s})$} \\
\hline Predicted & $3.5 \pm 0.7$ & $3.5 \pm 0.9$ & $3.5 \pm 1.0$ & .92 & .87 & .66 \\
\hline Before bronchodilator & $1.2 \pm 1.0$ & $1.8 \pm 1.1$ & $2.4 \pm 1.6$ & .001 & .09 & .001 \\
\hline After bronchodilator & $1.4 \pm 1.1$ & $1.8 \pm 0.8$ & $2.8 \pm 1.5$ & $<.001$ & .01 & .05 \\
\hline$\%$ predicted before treatment & $33 \pm 27$ & $57 \pm 30$ & $67 \pm 27$ & $<.001$ & .23 & .001 \\
\hline$\%$ predicted after treatment & $40 \pm 29$ & $54 \pm 26$ & $67 \pm 34$ & .004 & .13 & .02 \\
\hline \multicolumn{7}{|c|}{$\begin{array}{l}\text { values are mean } \pm \text { SD. } \\
* P \text { via independent } t \text { test for asthma-before-treatment group versus control group. } \\
\dagger P \text { via independent } t \text { test for asthma-after-treatment group versus control group. } \\
\ddagger P \text { via } t \text { test for asthma-before-treatment group versus asthma-after-treatment group. } \\
\mathrm{FVC}=\text { forced vital capacity. } \\
\mathrm{FEF}_{25-75}=\text { forced expiratory flow during the middle half of the } \mathrm{FVC} \text { maneuver }\end{array}$} \\
\hline
\end{tabular}

Table 3. Systemic Inflammatory Markers Before and After Treatment

\begin{tabular}{|c|c|c|c|c|}
\hline & \multicolumn{2}{|c|}{ Asthma Group $(\mathrm{n}=30)$} & \multirow{2}{*}{$\begin{array}{c}\text { Control } \\
\text { Group } \\
(\mathrm{n}=20)\end{array}$} & \multirow{2}{*}{$P^{*}$} \\
\hline & Before Treatment & After Treatment & & \\
\hline C-reactive protein $(\mathrm{mg} / \mathrm{dL})$ & $4.8 \pm 6.0$ & $2.4 \pm 5.4$ & $1.5 \pm 1.4$ & $<.001$ \\
\hline Total leukocyte count (cells/ $\mu \mathrm{L})$ & $8,936 \pm 2,592$ & $6,960 \pm 1,785$ & $7,741 \pm 1,924$ & $<.001$ \\
\hline Erythrocyte sedimentation rate $(\mathrm{mm} / \mathrm{h})$ & $24.8 \pm 12.3$ & $15.8 \pm 10.1$ & $15.3 \pm 6.5$ & $<.001$ \\
\hline Neutrophils (\%) & $60 \pm 14$ & $62 \pm 9$ & $59 \pm 9$ & $<.001$ \\
\hline Lymphocytes (\%) & $27 \pm 8$ & $27 \pm 8$ & $31 \pm 8$ & .70 \\
\hline Monocytes (\%) & $6 \pm 2$ & $6 \pm 2$ & $5 \pm 2$ & .32 \\
\hline Eosinophils (\%) & $6 \pm 8$ & $4 \pm 2$ & $3 \pm 3$ & .13 \\
\hline Basophils (\%) & $<1 \pm<1$ & $<1 \pm 1$ & $<1 \pm<1$ & .99 \\
\hline
\end{tabular}

inflammation, but it is not certain whether systemic inflammation does influence pulmonary function. Also it has to be ascertained whether the systemic inflammation in asthma is an epi-phenomenon of the pulmonary inflammation.

Since C-reactive protein and other acute-phase reactants are affected by various factors including asthma, cardio- vascular diseases, diabetes mellitus, and obesity, ${ }^{12-15}$ it is not easy to determine whether a high $\mathrm{C}$-reactive protein is due to systemic inflammation caused by asthma alone. In our study, we carefully excluded patients with diseases known to cause systemic inflammation, and observed the change in systemic inflammation in response to asthma treatment alone, avoiding any other medications that could 


\section{Systemic Inflammation and Its Response to Treatment in Patients With Asthma}

Table 4. Bivariate Analysis of Systemic Inflammatory Markers Versus Other Variables in the Asthma Group (no. $=30$ )

\begin{tabular}{|c|c|c|c|c|c|c|}
\hline & \multicolumn{2}{|c|}{ C-Reactive Protein } & \multicolumn{2}{|c|}{ Total Leukocyte Count } & \multicolumn{2}{|c|}{$\begin{array}{c}\text { Erythrocyte } \\
\text { Sedimentation Rate }\end{array}$} \\
\hline & $\mathrm{r}$ & $P$ & $\mathrm{r}$ & $P$ & $\mathrm{r}$ & $P$ \\
\hline Age & 0.44 & .01 & 0.23 & .23 & -0.05 & .78 \\
\hline Weight & 0.35 & .06 & 0.30 & .11 & 0.36 & .05 \\
\hline Height & -0.20 & .29 & -0.27 & .15 & 0.17 & .37 \\
\hline Body mass index & 0.65 & $<.001$ & 0.63 & .001 & 0.33 & .07 \\
\hline Waist/hip & -0.25 & .18 & -0.27 & .15 & -0.11 & .57 \\
\hline Skin-fold thickness & -0.07 & .73 & 0.08 & .69 & -0.14 & .47 \\
\hline Chest circumference & 0.12 & .52 & 0.15 & .44 & -0.06 & .77 \\
\hline Family size & 0.51 & .004 & 0.30 & .10 & -0.08 & .69 \\
\hline Duration of symptoms & -0.02 & .93 & -0.08 & .66 & 0.07 & .72 \\
\hline $\mathrm{FEV}_{1} \%$ predicted & -0.64 & .001 & -0.64 & .001 & -0.08 & .65 \\
\hline FVC $\%$ predicted & -0.39 & .03 & -0.31 & .09 & 0.14 & .45 \\
\hline $\mathrm{FEV}_{1} / \mathrm{FVC}$ & -0.71 & $<.001$ & -0.74 & $<.001$ & -0.15 & .42 \\
\hline $\mathrm{FEF}_{25-75}$ & -0.51 & .004 & -0.58 & .001 & -0.23 & .23 \\
\hline C-reactive protein & NA & NA & 0.80 & $<.001$ & 0.13 & .48 \\
\hline Total leukocyte count & 0.80 & $<.001$ & NA & NA & 0.07 & .71 \\
\hline Erythrocyte sedimentation rate & 0.13 & .49 & 0.07 & .71 & NA & NA \\
\hline Neutrophils & 0.27 & .15 & 0.44 & .02 & 0.06 & .74 \\
\hline Lymphocytes & -0.25 & .18 & -0.23 & .21 & -0.30 & .11 \\
\hline Monocytes & -0.03 & .88 & -0.01 & .97 & -0.34 & .06 \\
\hline Eosinophils & -0.16 & .39 & -0.26 & .17 & -0.08 & .67 \\
\hline Basophils & -0.17 & .38 & -0.11 & .58 & -0.32 & .08 \\
\hline $\begin{array}{l}\mathrm{FVC}=\text { forced vital capacity } \\
\mathrm{FEF}_{25-75}=\text { forced expiratory flow during } \\
\mathrm{NA}=\text { not applicable }\end{array}$ & f the for & maneuver & & & & \\
\hline
\end{tabular}

Table 5. Multiple Linear Regression Analysis of Systemic Inflammatory Markers Versus Other Variables in the Asthma Group (no. = 30)

\begin{tabular}{|c|c|c|c|c|c|c|}
\hline & \multicolumn{2}{|c|}{$\begin{array}{l}\text { C-Reactive Protein } \\
\left(\text { adjusted } \mathrm{r}^{2}=0.75\right)\end{array}$} & \multicolumn{2}{|c|}{$\begin{array}{c}\text { Erythrocyte } \\
\text { Sedimentation Rate } \\
\text { (adjusted } r^{2}=0.01 \text { ) }\end{array}$} & \multicolumn{2}{|c|}{$\begin{array}{l}\text { Total Leukocyte Count } \\
\text { (adjusted } \mathrm{r}^{2}=0.57 \text { ) }\end{array}$} \\
\hline & $\beta$ & $P$ & $\beta$ & $P$ & $\beta$ & $P$ \\
\hline Age & 0.31 & .008 & 0.02 & .91 & 0.11 & .42 \\
\hline Weight & -0.45 & .01 & 0.18 & .60 & -0.51 & .03 \\
\hline Body mass index & 0.99 & .001 & 0.39 & .47 & 0.65 & .08 \\
\hline Family size & 0.33 & .008 & $<0.01$ & .98 & 0.17 & .26 \\
\hline $\mathrm{FEV}_{1} \%$ predicted before treatment & $<0.01$ & .99 & 0.14 & .82 & -0.70 & .09 \\
\hline FVC $\%$ predicted before treatment & -0.04 & .86 & 0.23 & .56 & 0.42 & .11 \\
\hline
\end{tabular}

have affected inflammation. There was a significant reduction in all 3 markers, which suggests that the standard asthma treatment advised by the current guidelines can decrease systemic inflammation.

Many studies have found that obese patients have more severe asthma. Patients, especially women with BMI $>25 \mathrm{~kg} / \mathrm{m}^{2}$, are more susceptible to moderate to severe asthma. ${ }^{16}$ Also, obese patients are less likely than the nonobese patients to achieve asthma control with an inhaled corticosteroid or inhaled corticosteroid plus long-acting $\beta_{2}$ agonist. ${ }^{17}$ Consistent weight loss in severely obese asthma patients is associated with improved respiratory symptoms and lung function. ${ }^{18}$ Our results conform with those observations; we found a significant positive correlation of BMI with C-reactive protein. Other factors that significantly correlated with C-reactive protein were age and family size. On the other hand, erythrocyte sedimentation rate and total leukocyte count did not significantly corre- 
late with age, BMI, or family size. It is unclear how and to what extent these factors contribute to systemic inflammation in asthma patients. ${ }^{19}$ The sensitivity of these inflammation markers to various factors indicates that $\mathrm{C}$-reactive protein may serve as a better marker than other markers, which will be an area of further research.

Our findings clearly point towards vital facts about asthma and its treatment. First, that background systemic inflammation is present in asthma, as it is in other chronic diseases, and second, that the systemic inflammation responds to standard asthma-control measures.

\section{Limitations}

The major limitation of our study was its study design. A randomized controlled trial would have eliminated confounding due to demographic factors and further elucidated the effect of different treatment aspects on the systemic-inflammation markers. There can be generalization issues towards the population from which the sample is selected due to the small sample size of the groups, which also reduces the power of analysis. Also, the follow-up duration was not long enough to assess the sustainability of the reduction in systemic-inflammation markers after treatment.

\section{Conclusions}

Systemic inflammation in asthma patients correlated with less favorable respiratory function, and decreased in response to standard asthma treatment. Further studies are required to determine the treatment needed to sustain the inflammation reduction and to determine the importance of systemic inflammation in asthma and overall health status.

\section{REFERENCES}

1. Jousilahti PSV, Hakala K, Rasi V, Vahtera E, Palosuo T. The association of sensitive systemic inflammation markers with bronchial asthma. Ann Allergy Asthma Immunol 2002;89(4):381-385.

2. Olafsdottir IS, Gislason T, Thjodleifsson B, Olafsson I, Gislason D, Jogi R, Janson C. C-reactive protein levels are increased in nonallergic but not allergic asthma: a multicentre epidemiological study. Thorax 2005;60(6):451-454.

3. Takemura M, Matsumoto H, Nilmi A, Ueda T, Matsuoka H, Yamaguchi M, et al. High sensitivity C-reactive protein in asthma. Eur Respir J 2006;27(5):908-912.
4. Global Initiative for Asthma (GINA); National Heart, Lung and Blood Institute (NHLBI). Global strategy for asthma management and prevention. Bethesda, MD; Updated 2010. http://www.ginasthma. com/Guidelineitem.asp??11 $=2 \& 12=1 \&$ intId $=60$. Accessed April 11, 2011.

5. Enright P, Ward BJ, Tracy RP, Lasser EC. Asthma and its association with cardiovascular disease in the elderly. J Asthma 1996;33(1): 45-53.

6. Tracy RP. Inflammation in cardiovascular disease: cart, horse, or both? (editorial). Circulation 1998;97(20):2000-2002.

7. Rifai N, Tracy RP, Ridker PM. Clinical efficacy of an automated high-sensitivity C-reactive protein assay. Clin Chem 1999;45(12): 2136-2141.

8. Roberts WL, Sedrick R, Moulton L, Spencer A, Rifai N. Evaluation of four automated high-sensitivity C-reactive protein methods: implications for clinical and epidemiological applications. Clin Chem 2000;46(4):461-468.

9. Roberts WL, Moulton L, Law TC, Farrow G, Cooper-Anderson M, Savory J, Rifai N. Evaluation of nine automated high sensitivity C-reactive protein methods: Implications for clinical and epidemiological applications. Part 2. Clin Chem 2001;47(3):418-425.

10. Kony S, Zureik M, Driss F, Neukirch C, Leynaert B, and Neukirch F. Association of bronchial hyperresponsiveness and lung function with $\mathrm{C}$ - reactive protein (CRP): a population based study. Thorax 2004;59(10):892-896.

11. Knudson RJ, Lebowitz MD, Holberg CJ, Burrows B. Changes in the normal maximal expiratory flow-volume curve with growth and aging. Am Rev Respir Dis 1983;127(6):725-734.

12. Pradhan AD, Manson JE, Rifai N, Buring JE, Ridker PM. C-reactive protein, interleukin 6 , and risk of developing type 2 diabetes mellitus. JAMA 2001;286(3):327-334.

13. Visser M, Bouter LM, McQuillen GM, Wener MH, Harris TB. Elevated C-reactive protein levels in overweight and obese adults. JAMA 1999;282(22):2131-2135.

14. Yudkin JS, Stehouwer CDA, Emeis JJ, Coppack SW. C-reactive protein in healthy subjects: association with obesity, insulin resistance, and endothelial dysfunction: a potential role for cytokines originating from adipose tissue? Arterioscler Thromb Vasc Biol 1999; (4): 19:972-978

15. Earl SF. Asthma, body mass index, and C-reactive protein among US adults. J Asthma 2003;40(7):733-739.

16. Hernández Velásquez L, Segura Méndez NH. Relation between asthma severity and body mass index. Case series. Rev Alerg Mex 2007;54(4):107-110.

17. Boulet LP, Franssen E. Influence of obesity on response to fluticasone with or without salmeterol in moderate asthma. Respir Med 2007;101(11):2240-2247.

18. Maniscalco M, Zedda A, Faraone S, Cerbone MR, Cristiano S, Giardiello C, Sofia M. Weight loss and asthma control in severely obese asthmatic females. Respir Med 2008;102(1):102-128.

19. Sin DD, Lacy P, York E, Man SF. Effects of fluticasone on systemic markers of inflammation in COPD. Am J Respir Crit Care Med 2004;170(7):760-765. 